Gitation: Osorio Espinoza, H.,

Aguirre-Cadena, J. F., Pérez de la O, N. B., Brindis-Santos, A. I., \& MarroquínAgreda, F.J. (2021) Agroecological coverings for the sustainable production of Rambutan (Nephelium lappaceum L.). Agro Productividad. https://doi. org/10.32854/agrop.v14i9.2143

Editor in Chief: Dr. Jorge Cadena Iñiguez

Received: March 14, 2021. Accepted: August 19, 2021. Published on-line: October 14, 2021

This work is licensed under a Creative Commons Attribution-NonCommercial 4.0 International license.

\section{Agroecological coverings for the sustainable production of Rambutan (Nephelium lappaceum L.)}

\author{
Osorio Espinoza, Humberto ${ }^{1}$; Aguirre-Cadena, Juan F. ${ }^{{ }^{*}}$; Pérez de la O, Nidia Bélgica ${ }^{2}$; \\ Brindis-Santos, Alfredo I. ${ }^{1}$; Marroquín-Agreda, Francisco J. ${ }^{1}$ \\ 1 Universidad Autónoma de Chiapas, Facultad de Ciencias Agrícolas, Entronque Carretera Costera y Pueblo \\ de Huehuetán, Huehuetán, Chiapas, México. C.P. 30660. Tel. 01 (964) 6270128 y 620439. \\ 2 Posgrado en Fitosanidad-Entomología y Acarología, Colegio de Postgraduados, Carretera México-Texcoco \\ km 36.5, 56230 Estado de México, México. \\ * Correspondence: juan.cadena@unach.mx
}

\begin{abstract}
Objective: To evaluate the influence of living and dead covers on the yield and quality of rambutan fruits (Nephelium lappaceum L.) in Soconusco, Chiapas, Mexico.

Design/methodology/approach: Five treatments were evaluated, two live covers, two dead covers and an always clean control without covers. The following were evaluated: plant height, crown volume, fruit quality, fruit yield $\left(\mathrm{t} \mathrm{ha}^{-1}\right)$. The data were analyzed under a randomized block experimental design.

Results: All the agroecological modalities of hedging evaluated produced fruits with the quality required for national and international commercialization.

Study limitations/implications: The morphological and physiological response of the crop can change with the age of the tree.

Findings/conclusions: An agroecological management strategy is presented to develop rambutan cultivation in Soconusco region.
\end{abstract}

Keywords: Covers, Rambutan, Agroecology, quality of fruits.

\section{INTRODUGTION}

Rambutan (Nephelium lappaceum L.) is a tropical fruit native to the Malay Archipelago that belongs to the Sapindaceae family (Tindall, 1994). It was introduced around 1960 into Soconusco, Chiapas, Mexico, where it adapted to the warm-humid environment, a condition which has favored its expansion in the last years. The fruit is consumed fresh due to its sweet flavor, juicy pulp, vitamin $\mathrm{G}$ and riboflavin content (Pérez \& Jürgen, 2004). Additionally, it has been found that it contains polyphenolic compound bioactives (Hernández et al., 2017; Ling et al., 2010; Thitilertdecha et al., 2010), antimicrobial activity (Mohamed et al., 1994; Solanki, 2010), and antihyperglycemic activity (Palanisamy et al., 
2011; Manaharan et al., 2012), which are considered natural compounds with both high added value and high antioxidant activity.

At present, there are more than 2000 ha of rambutan crops in Chiapas, ranging from 100 to $700 \mathrm{~m}$ of altitude, which have allowed the region to diversify with regards to production and economy (Caballero et al., 2011). This crop has also been established in other regions of Mexico, like Veracruz, Tabasco, and Nayarit (García-Gurría et al., 2013). The production of rambutan as a traditional monoculture produces an average yield of $10 \mathrm{t} \mathrm{ha}^{-1}$ year (SIAP, 2020) with the use of high amounts of agrochemicals (SAGARPA, 2015). Moreover, these technologies include non-quantified energy expenditure, which diminishes crop profitability while it leads to phreatic surface contamination with collateral damage to wild flora, whose function is to maintain ecological balance of agroecosystems (Ruiz et al., 2013). In view of this situation, some agroecological practices, such as the use of live and dead covers, have proven their efficiency in crop management and weed management (Cairo et al., 2017). These practices allow the conservation of soil moisture (Leyva, 2002; Vanderlinden et al., 2004; Gómez et al., 2017), and boost the number and diversity of macro-organisms (Toledo, 2008). As for rambutan, there is no research done with such purposes. Therefore, the objective of the research hereby presented was to evaluate the influence of live and dead covers on the yield and quality of rambutan fruits.

\section{METHODS AND MATERIALS}

The research was carried out in the Cantón Barrio Nuevo, Villa Comaltitlán municipality $\left(15^{\circ} 08^{\prime} 7,14^{\prime \prime} \mathrm{N}\right.$ and $\left.92^{\circ} 37^{\prime} 32,11^{\prime \prime} \mathrm{O}\right)$ at $23 \mathrm{~m}$ of altitude. The climate corresponds to type Aw (w”) IG, with $2500 \mathrm{~mm}$ of annual rainfall, distributed between June to November, and an annual average temperature of $23^{\circ} \mathrm{C}$ (García, 1973). The experimental area is characterized by having moderately fertile soil and classified as a cambic, deep Feozem, with a sandy crumb texture, granular structure, slightly acidic $\mathrm{pH}(6.0)$, low organic matter content (2.6\%), $0.07 \% \mathrm{~N}, 26.6 \mathrm{mg} \mathrm{kg}^{-1} \mathrm{P}, 230.0 \mathrm{mg} \mathrm{kg}^{-1} \mathrm{~K}, 804 \mathrm{mg} \mathrm{kg}^{-1} \mathrm{Ca}, 457.5 \mathrm{mg}$ $\mathrm{kg}^{-1} \mathrm{Mg}$, and $168.0 \mathrm{mg} \mathrm{kg}^{-1} \mathrm{Na}$ (USS, Working Group WRB, 2015).

Uniformly growing 18-month-old rambutan plants of the Adelita variety were acquired. The cultivation was done on November 8,2009 , through a $7 \times 7 \mathrm{~m}$ spatial arrangement (Fraire, 2001).

We set live and dead covers and a core with no cover 15 days after the cultivation, under an experimental design of random blocks with 5 treatments and four replications. The covers were established from the base of the rambutan plant and over the soil surface up to $2 \mathrm{~m}$ away at the cardinal points. A total of $16 \mathrm{~m}^{2}$ were covered.

The treatments were as follows:

1. Arachis pintoi Krapov. \& W. G. Greg cover (ApC). A. pintoi stolons were set at a rate of 12 stolons $15-20 \mathrm{~cm}$ long and with 5 to 6 knots per $\mathrm{m}^{2}$. After sowing, the cultivated area was irrigated with 32 liters of water, in two applications with 30-minute intervals.

2. Weeds cover (WeC). The population of weeds was kept and was pruned with a machete and by hand to $0,20 \mathrm{~m}$ high. 
3. Rambutan crop residues cover (RCR). The rambutan pruning residues were cut and spread in $0,10 \mathrm{~m}$ pieces over the soil surface at an average height of $0,20 \mathrm{~m}$.

4. Cover including short-cycle crop residues (corn straws, beans, and sesame) and weeds (CRW). The area was covered with the crop residues and the rest was maintained with weeds at $0,20 \mathrm{~m}$ high.

5. Uncovered core with herbicides (UCC). Herbicide paraquat was used, six times a year, four during rainy period and two during dry period, at the rate of $2.0 \mathrm{~L}$ $\mathrm{ha}^{-1}$. When the effect of paraquat concluded, the same dose of glyphosate was used covering $16 \mathrm{~m}^{2}$ from the base of the rambutan plant. The surviving species were extracted manually.

All five treatments were set in an experimental design of randomized blocks with four replications. A tree was considered as one experimental unit.

Plant Height variables were recorded bimonthly from 2009. They were obtained using a graduated ruler $4 \mathrm{~m}$ long (Error $\pm 0,01 \mathrm{~m}$ ). The crown volume was measured bimonthly from 2011 to 2014. Crown volume was estimated from the equatorial diameter, using a measuring tape (Error $\pm 0,01 \mathrm{~m}$ ) at a medium height of the crown in two directions (N-S and E-W), and crown height was measured with a graduated ruler $4 \mathrm{~m}$ long (Error $\pm 0,01 \mathrm{~m}$ ). The total number of fruits was counted per treatment and replication. The Weight of the fruits (g) was achieved by weighing them individually on a digital scale (Ohaus ${ }^{\circledR}$ USA) with a sensitivity of $0.01 \mathrm{~g}$. Degrees Brix ( ${ }^{\circ}$ Brix) were obtained in 30 fruits per plant and taken at the four cardinal points at two different heights of the plant with a refractometer (ATAGO Model Pallete PR-32 USA: 0-32\%) following the AOAC methodology (1990). $\mathrm{pH}$ was obtained with a potentiometer (Thermo Orion, Modelo 230A USA). Titratable acidity quantification (expressed as \% citric acid) was measured by means of the volumetric method of AOAC (2000).

\section{Statistical analysis}

The data obtained were processed with the help of Statgraphics Centurion XVI.I software. A variance analysis (ANOVA) was conducted to establish the statistical difference. When differences were found, the comparison of Duncan's means was carried out $(\mathrm{P} \leq 0,05)$.

\section{Economic Analysis}

The economic evaluation was calculated considering the SAGARPA proposal (2014), which contemplates: (i) the direct costs of the work and inputs used for treatments, (ii) the indirect costs during the experimental phase, and (iii) the economic results of the three rambutan harvests. To determine the total benefits per treatment (in Mexican pesos), the total investment (benefit-cost-ratio) was subtracted from the gross income.

\section{RESULTS AND DISGUSSION}

\section{Plant height and Grown volume}

The results obtained show that the covers did not influence both variables. There were no significant differences between the treatments during the experimental period (Table 1). 
Table 1. Height and crown volume in Nephelium lappaceum L., with different coverage treatments in Soconusco, Chiapas, Mexico, area for five years. The values are averages of four repetitions and without statistical difference $(\mathrm{P} \leq 0.05)$.

\begin{tabular}{|c|c|c|c|c|c|c|c|c|c|c|c|}
\hline \multirow{2}{*}{ Year } & \multirow{2}{*}{ Date } & \multicolumn{5}{|c|}{ Plant height (m) } & \multicolumn{5}{|c|}{ Crown volume $\left(\mathrm{m}^{3}\right)$} \\
\hline & & ApG & WeG & RGR & GRW & UCG & ApC & WeG & RCR & GRW & UCG \\
\hline 2009 & Nov & 1.11 & 1.11 & 1.11 & 1.11 & 1.11 & & & & & \\
\hline \multirow{6}{*}{2010} & Jan & 1.16 & 1.13 & 1.13 & 1.13 & 1.13 & & & & & \\
\hline & Mar & 1.22 & 1.21 & 1.21 & 1.22 & 1.22 & & & & & \\
\hline & May & 1.29 & 1.28 & 1.29 & 1.30 & 1.31 & & & & & \\
\hline & Jul & 1.40 & 1.38 & 1.36 & 1.41 & 1.42 & & & & & \\
\hline & Sep & 1.52 & 1.51 & 1.44 & 1.51 & 1.51 & & & & & \\
\hline & Nov & 1.64 & 1.60 & 1.54 & 1.64 & 1.65 & & & & & \\
\hline \multirow{6}{*}{2011} & Jan & 1.76 & 1.72 & 1.62 & 1.71 & 1.75 & 3.03 & 2.41 & 1.77 & 2.68 & 3.12 \\
\hline & Mar & 1.88 & 1.77 & 1.70 & 1.76 & 1.82 & 4.11 & 2.93 & 2.24 & 3.05 & 3.70 \\
\hline & May & 1.94 & 1.82 & 1.75 & 1.81 & 1.87 & 4.70 & 3.29 & 2.59 & 3.46 & 4.16 \\
\hline & Jul & 2.13 & 2.11 & 1.87 & 1.90 & 1.95 & 6.86 & 5.96 & 3.52 & 4.33 & 5.03 \\
\hline & Sep & 2.25 & 2.29 & 2.03 & 2.02 & 2.14 & 8.56 & 8.04 & 5.07 & 5.66 & 7.31 \\
\hline & Nov & 2.37 & 2.41 & 2.21 & 2.17 & 2.27 & 11.04 & 10.39 & 7.55 & 7.87 & 9.20 \\
\hline \multirow{6}{*}{2012} & Jan & 2.43 & 2.49 & 2.28 & 2.27 & 2.35 & 12.29 & 11.68 & 8.63 & 9.44 & 10.58 \\
\hline & Mar & 2.56 & 2.54 & 2.38 & 2.34 & 2.42 & 14.76 & 13.13 & 10.08 & 10.48 & 11.81 \\
\hline & May & 2.64 & 2.59 & 2.44 & 2.36 & 2.45 & 15.00 & 13.33 & 11.14 & 11.88 & 11.84 \\
\hline & Jul & 2.72 & 2.64 & 2.49 & 2.46 & 2.51 & 16.32 & 14.38 & 12.33 & 12.53 & 12.41 \\
\hline & Sep & 2.75 & 2.67 & 2.52 & 2.51 & 2.54 & 17.70 & 15.26 & 13.00 & 13.14 & 13.27 \\
\hline & Nov & 2.79 & 2.69 & 2.55 & 2.56 & 2.57 & 18.53 & 16.82 & 14.38 & 14.68 & 14.70 \\
\hline \multirow{6}{*}{2013} & Jan & 2.82 & 2.75 & 2.67 & 2.71 & 2.69 & 19.37 & 17.99 & 15.74 & 18.24 & 16.06 \\
\hline & Mar & 2.84 & 2.81 & 2.75 & 2.82 & 2.76 & 20.33 & 19.13 & 17.63 & 18.72 & 17.41 \\
\hline & May & 2.87 & 2.83 & 2.79 & 2.89 & 2.80 & 21.12 & 19.80 & 17.79 & 18.87 & 18.02 \\
\hline & Jul & 3.00 & 2.88 & 2.78 & 2.95 & 2.83 & 21.46 & 19.97 & 18.89 & 20.76 & 19.23 \\
\hline & Sep & 3.06 & 2.91 & 2.77 & 2.99 & 2.85 & 24.91 & 23.97 & 22.52 & 23.66 & 22.18 \\
\hline & Nov & 3.13 & 2.94 & 2.77 & 3.02 & 2.87 & 27.60 & 25.98 & 25.05 & 26.38 & 25.01 \\
\hline \multirow{6}{*}{2014} & Jan & 3.26 & 3.13 & 2.96 & 3.23 & 3.03 & 30.46 & 28.21 & 27.15 & 29.54 & 27.13 \\
\hline & Mar & 3.32 & 3.29 & 3.18 & 3.29 & 3.17 & 35.05 & 30.08 & 30.16 & 34.06 & 30.38 \\
\hline & May & 3.37 & 3.32 & 3.25 & 3.30 & 3.18 & 35.20 & 30.17 & 30.29 & 34.19 & 30.55 \\
\hline & $\mathrm{Jul}$ & 3.41 & 3.34 & 3.30 & 3.37 & 3.20 & 35.29 & 30.25 & 30.43 & 34.60 & 30.64 \\
\hline & Sep & 3.42 & 3.35 & 3.32 & 3.40 & 3.22 & 37.91 & 33.59 & 33.36 & 37.07 & 32.24 \\
\hline & Nov & 3.64 & 3.56 & 3.55 & 3.64 & 3.43 & 39.79 & 37.09 & 36.29 & 39.25 & 36.00 \\
\hline
\end{tabular}

ApC (Arachis pintoi Krapov. \& W. G. Greg cover), WeC (Weeds cover), RCR (Rambutan crop residues cover), RCR (Rambutan crop residues cover), UCG (Uncovered core with herbicides).

The plants reached an average height of 3,3 $\mathrm{m}$ by the end of 2014. Plant height of fruit trees is a growth variable closely linked to crop yield, and, from the practical point of view, it is of great importance as harvesting fruits more easily or vice versa depends on that. The architecture of the rambutan plant shows that the side branches define productivity. 
The initial growth of the crown volume in the ApC treatment increased from the second year, a trend maintained until the last sampling. In contrast, the CRW treatment produced the smallest crown size during evaluation.

At the end of the third harvest, the core, $\mathrm{WeC}$ and RCR had the smallest crown size while ApC and CRW reached a significantly higher development. In this regard, Barreto et al. (2015) explain that plants produced by grafting the same variety grow in a similar way if set in similar edaphoclimatic conditions. This suggests covers contribute to it, mainly with Arachis pintoi (ApC) by improving soil fertility through the activity of nitrogen-fixing bacteria and moisture conservation with GRW.

In general, throughout the March-July period there is a greater increase in the plant growth, which coincides with the induction of the flowering-fruiting stage. This effect in the region was pointed out by Fraire (2001). The treatments with the greatest increase in crown volumes (ApC and CRW), close to $40 \mathrm{~m}^{3}$ and compared to the rest of the treatments, show a difference of about $4 \mathrm{~m}^{3}$. The increase in crown volume may be related to fruit production and the volume of branches that must be pruned on each tree, after harvests. This morphological expression may influence the results of subsequent harvests (Doruska and Burkhart, 1994 and Brunner, 1998).

\section{Influence of the covers on the quality of the fruits}

The results show significant statistical differences $(p \leq 0.05)$ in the weight of the fruit and the ${ }^{\circ}$ Brix. In the case of fruit acidity and $\mathrm{pH}$, there are no significant differences over the years (Table 2). However, the quality of rambutan fruits for export is considered optimal when they reach a weight greater than $30 \mathrm{~g}$ and a total soluble solids content of 16 to 18\% (Codex Alimentarius, 2008), in addition to presenting a uniform red color, free of lesions and pest damage. In our case, fruit mass was greater than $30 \mathrm{~g}$, including the core.

A less efficient result was expected with the WeC treatment, that is, smaller fruits, when considering the weeds competition for nutrients and water with rambutan; however, up to now, only in the second year of harvest, lower weight was obtained in comparison with the other treatments. On the other hand, the treatment without weeds (UCC), produced fruits of greater size in the years 2013 and 2014 which was statistically superior to the rest of the treatments $(\mathrm{p} \leq 0.05)$.

In general, ApC treatment was considered to produce better results. This was partially because it was easier to set Arachis pinto $i$ under the shade of the rambutan and because of its promiscuous condition of association with rhizobia, which is capable of fixing nitrogen and improving the nitrogen supply to the plant.

Rambutan residues covers (RCR) and annual crop residues (CRW) had intermediate values during the three years of production. In 2013 all treatments decreased their fruit weight, which increased in the following year. This could have been due to environmental conditions. ${ }^{\circ}$ Brix content in the fruits differed between years and treatments, with no apparent relationship. They increased with $\mathrm{WeC}$ and RCR in the first year, and only RCR was again statistically different from other treatments in 2014. WeG was inserted into the first statistical group only the first year and ApC in the last. Rambutan is a crop that 
can reach productions that fluctuate between 12 and $16 \mathrm{t} \mathrm{ha}^{-1}$ in Chiapas (Fraire, 2001). These productions can be achieved after crop yield stabilization, which occurs after the sixth harvest (Arias and Calvo, 2014).

Table 2. Fruit weight Evaluation of the quality of Nephelium lappaceum L., fruits three years after being set with different covers in Soconusco, Chiapas, Mexico.

\begin{tabular}{|c|c|c|c|}
\hline \multirow{2}{*}{ Treatments } & \multicolumn{3}{|c|}{ Fruit weight (g) } \\
\hline & 2012 & 2013 & 2014 \\
\hline ApC & $35,0 \mathrm{~b}$ & $33,4 \mathrm{~b}$ & $32,3 \mathrm{bc}$ \\
\hline WeG & $31,8 \mathrm{~d}$ & $27,3 \mathrm{~d}$ & $32,9 \mathrm{bc}$ \\
\hline RCR & $37,4 \mathrm{a}$ & $31,9 \mathrm{c}$ & $31,1 \mathrm{c}$ \\
\hline CRW & $33,2 \mathrm{c}$ & $30,8 \mathrm{~b}$ & $33,2 \mathrm{~b}$ \\
\hline UCG & $31,9 \mathrm{~d}$ & $37,2 \mathrm{a}$ & $34,0 \mathrm{a}$ \\
\hline $\mathrm{CV} \%$ & 6,51 & 10,60 & 4,93 \\
\hline $\mathrm{SE}$ & 0,281 & 0,494 & 0,438 \\
\hline \multicolumn{4}{|c|}{ Acidity } \\
\hline ApC & 1,67 & 1,64 & 1,69 \\
\hline WeG & 1,55 & 1,59 & 1,44 \\
\hline RCR & 1,54 & 1,56 & 1,52 \\
\hline CRW & 1,66 & 1,64 & 1,69 \\
\hline UCG & 1,64 & 1,62 & 1,64 \\
\hline $\mathrm{CV} \%$ & 7,43 & 3,79 & 14,36 \\
\hline $\mathrm{SE}$ & 0,047 & 0,021 & 0,09 \\
\hline \multicolumn{4}{|c|}{$\mathrm{pH}$} \\
\hline ApC & 4,66 & 4,68 & 4,65 \\
\hline WeG & 4,67 & 4,59 & 4,74 \\
\hline RCR & 4,68 & 4,63 & 4,68 \\
\hline CRW & 4,68 & 4,68 & 4,68 \\
\hline $\mathrm{UCC}$ & 4,62 & 4,66 & 4,60 \\
\hline $\mathrm{CV} \%$ & 1,54 & 1,16 & 4,22 \\
\hline $\mathrm{SE}$ & 0,023 & 0,019 & 0,063 \\
\hline \multicolumn{4}{|c|}{${ }^{\mathrm{o}}$ Brix } \\
\hline ApC & $19,0 \mathrm{ab}$ & $20,1 \mathrm{~b}$ & $20,6 \mathrm{a}$ \\
\hline WeC & $20,1 \mathrm{a}$ & $18,9 \mathrm{c}$ & $19,0 \mathrm{bc}$ \\
\hline RCR & $19,0 \mathrm{a}$ & $20,2 \mathrm{~b}$ & $20,7 \mathrm{a}$ \\
\hline CRW & $17,9 \mathrm{~b}$ & $21,4 \mathrm{a}$ & $19,9 \mathrm{ba}$ \\
\hline UCG & $19,0 \mathrm{ab}$ & $20,9 \mathrm{ab}$ & $19,2 \mathrm{cb}$ \\
\hline $\mathrm{CV} \%$ & 7,22 & 5,87 & 6,85 \\
\hline $\mathrm{SE}$ & 0,509 & 0,318 & 0,467 \\
\hline
\end{tabular}

ApC (Arachis pintoi Krapov. \& W. C. Greg cover), WeC (Weeds cover), RCR (Rambutan crop residues cover), RGR (Rambutan crop residues cover), UCG (Uncovered core with herbicides). Means with different letters in each column, indicate significant statistical differences according to Duncan $(\mathrm{P} \leq 0.05)$. CV: Coefficient of Variation. SE: Estandard Error. 


\section{Influence of covers on rambutan crop yield}

The analysis of the first three harvests (Table 3) showed that for the first two harvests the influence of covers was extremely low and highly variable between treatments, which usually occurs with all perennial fruit trees.

The highest fruit yield was achieved with the treatment where protection with CRW was used and was statistically different in the three harvest years compared to the rest of the treatments. ApC also achieved the highest fruit production during 2014 and is positioned as the second-best option in yield. In this case, it is considered as an alternative of great validity as it favors the presence of beneficial entomofauna for the pollination of the crop flowers, and, therefore, for greater fruit production (Marroquín et al., 2015).

WeC treatment produced the lowest yields of all the treatments in the three harvests. This suggests interspecific competition crop-weeds for light, water, and nutrients, during the growth and development of crops under adequate spatial arrangements (Franke, 1995).

However, the results obtained confirm the benefits of covers and the disadvantages of keeping the soil uncovered, corroborating what Febles et al. (2010) proposed regarding the effectiveness of the cover to protect the soil against erosion, solar radiation, rains, winds, weed and extreme temperatures.

The results obtained shed light on the importance of the agroecological view of considering any living or dead cover for the benefit of the crop compared to bare soil.

\section{Economic evaluation of rambutan cultivation with a cover}

The profitability of the two best treatments (CRW and ApC) amounted to 163000 Mexican pesos. Harvest with ApC contributed the most with more than $80 \%$ of the profits (Table 4).

Table 3. Rambutan crop (Nephelium lappaceum L.) yield with different cover treatments in the first years of harvest in Soconusco, Chiapas, Mexico.

\begin{tabular}{c|c|c|c|}
\hline \multirow{2}{*}{ Treatments } & \multicolumn{3}{|c|}{ Performance $\left(\mathbf{t ~ h a}^{-\mathbf{1}}\right)$} \\
\cline { 2 - 4 } & $\mathbf{2 0 1 2}$ & $\mathbf{2 0 1 3}$ & $\mathbf{2 0 1 4}$ \\
\hline ApC & $0,604 \mathrm{~b}$ & $3,055 \mathrm{~b}$ & $11,694 \mathrm{a}$ \\
\hline $\mathrm{WeC}$ & $0,459 \mathrm{~cd}$ & $2,383 \mathrm{e}$ & $8,640 \mathrm{c}$ \\
\hline RCR & $0,497 \mathrm{c}$ & $2,811 \mathrm{c}$ & $10,133 \mathrm{~b}$ \\
\hline CRW & $0,716 \mathrm{a}$ & $3,269 \mathrm{a}$ & $11,555 \mathrm{a}$ \\
\hline UCG & $0,417 \mathrm{~d}$ & $2,516 \mathrm{~d}$ & $10,409 \mathrm{~b}$ \\
\hline GV $\%$ & 23,95 & 13,02 & 13,33 \\
\hline SE & 0,023 & 0,044 & 0,336 \\
\hline
\end{tabular}

ApC (Arachis pintoi Krapov. \& W. C. Greg cover), WeC (Weeds cover), RCR (Rambutan crop residues cover), RCR (Rambutan crop residues cover), UCG (Uncovered core with herbicides). Means with different letters in each column, indicate significant statistical differences according to Duncan $(\mathrm{P} \pm 0,05)$.

GV: Coefficient of Variation. SE: Estandard Error. 
Table 4. Economic evaluation of Nephelium lappaceum L. fruit production with different covers in the Soconusco, Chiapas, Mexico.

\begin{tabular}{l|c|c|c|c|c}
\hline & ApG & WeG & RCR & GRW & UCG \\
\hline Establishment Costs $\left(\$ / \mathrm{ha}^{-1}\right)$ & 50337,00 & 50237,00 & 50137,00 & 50137,00 & 76037,00 \\
\hline Maintenance costs $\left(\$ / \mathrm{ha}^{-1}\right)$ & 14650,00 & 15470,00 & 15670,00 & 15470,00 & 18730,00 \\
\hline Income & 227595,00 & 173085,00 & 204105,00 & 229485,00 & 200055,00 \\
\hline Net Profit $\left(\$ / \mathrm{ha}^{-1}\right)$ & 162068,00 & 107378,00 & 138298,00 & 163878,00 & 105288,00 \\
\hline
\end{tabular}

ApC (Arachis pintoi Krapov. \& W. C. Greg cover), WeC (Weeds cover), RCR (Rambutan crop residues cover), RCR (Rambutan crop residues cover), UCG (Uncovered core with herbicides).

Both treatments can be successful from an agroecological point of view. While dead covers with crop residues offer protection from the moment they are applied, live covers take time to offer such protection. One advantage of the latter is that they can attract beneficial insects, although they retain less moisture compared to dead covers. Therefore, each alternative must be adjusted to the main interest of farmers, considering that both are as efficient economically speaking.

The least successful treatment was UCG with a utility similar to the conservation of regulated natural vegetation $(\mathrm{WeC})$. Both treatments were surpassed by CRW with a difference that fluctuated between $\$ 56,000$ and $\$ 58,000$ Mexican pesos (US\$ 2,800-2,900). The treatment with the use of herbicides (UCG) was less efficient in terms of profitability, as it increases the main crop production costs, facilitates erosion and loss of soil moisture, apart from reducing biodiversity within the agroecosystem, which is counterproductive for the conservation of agroecosystems considering the problems caused by climate change.

\section{CONGLUSIONS}

A. pintoi live covers and crop residues covers used in rambutan harvesting do not limit the growth, yield, and quality of rambutan crop fruits regarding national and international commerce. This research project generated a strategic proposal aimed at enhancing sustainable rambutan harvesting for all producers with increased opportunities for national and international trade.

\section{REFERENCES}

Aguilar, O. (2007). Control transnacional del sistema productivo comercial del maíz sinaloense, En Sinaloa en la globalización: costos ecológicos, sociales y económicos, coordinados por ídem.; y Carlos Javier Maya. México: Plaza y Valdés Editores, Universidad Autónoma de Sinaloa. pp. 165-195.

AOAC (The Association of Official Analytical Chemists). (2000). Official methods, Assoc. Off. Anal. Chem. Int. (AOAC), Arlington, VA, U.S.A., 2000.

Arias, T. M., Calvo, V. I. (2014). El cultivo de Rambután o Mamón Chino. San José. Costa Rica. 88 p.

Barreto, L. F., De Andrade, R.A., Barreto. R.G., De Paula. L.C., De Lima, L.L., Martínez, A. B. G. (2015). Characterization of rambutan plants by foliar aspects. Afr. J. Agric. Res. 10(36): 3607-3613. Doi: 10.5897/AJAR2015.9651

Bello, E., Naranjo, E., Byame, R. (2010). Innovación socio ambiental y desarrollo ambiental en la frontera sur de México. México. REDISA-EGOSUR-CONACYT. 57 p.

Brunner, A. (1998). A light model for spatially explicit forest stand models. For. Ecol. Manage. 147: 19-46.

Caballero-Pérez, J. F., Arévalo-Galarza, L., Avendaño-Arrazate, C. H., Cadena-Íñiguez, J., Valdovinos-Ponce, G., Aguirre-Medina, J. F. (2011). Cambios físicos y bioquímicos durante el desarrollo y senescencia de frutos de rambután (Nephelium lappaceum L.). Revista Chapingo Serie Horticultura 17(1): 31-38 
Codex Alimentarius 246. (2005). "Norma del Codex estándar para rambután”. Organización de las Naciones Unidas para la Alimentación y la Agricultura. Roma. Italia. 4p. Disponible en: http://www. codexalimentarius.net/web/styard_list.do?lang=es (Consulta realizada el 19 de noviembre de 2016).

Comité Estatal de Información Estadística y Geográfica. (CEIEG). 2011. Disponible en: http://www.ceieg. chiapas.gob.mx/perfiles/PHistoricoIndex.php?region=071yoption=1\#. Fecha de consulta: 01 de octubre de 2011.

Doruska, D. F., Burkhart H. E. (1994). Modelling the diameter and locational distribution of branches within the crowns of loblolly pine trees in untinned plantations. Can. J. For. Res. 24: 2362-2376.

Fletes, H. Macías. A., Madera. J. (2014). El papel de los pequeños productores en la agricultura y alimentación. La experiencia desde tres regiones agrícolas en México. Plaza y Valdés. México. 45 p.

Fletes, H., Ocampo, G., Sánchez, M. 2014 b. Between food security and food sovereignty. Contradictory paths in Southern México. Ponencia en 113th Anual Meeting of the American Anthropological Association "Producing Anthropology". December 3-7. Washington. D. C. USA.

Flores, R. (2017). Alternancy Study on Rambutan (Nephelium lappaceum L.) Tree in Mexico. American Journal of Plant Sciences. 8 (1). 40-52. Doi: 10.4236/ajps.2017.81004

Fraire, V. G. 2001. El Rambután: Alternativa para la producción frutícola del trópico húmedo de México. INIFAP. Tuxtla Chico, Chiapas, México. Folleto Técnico No.1, 57 p.

Franke, G. 1995. Nutzpflanzen der Tropen und Suptropen. Bd. 1: Allgemeiner Pflanzenbau. UTB Ulmer Stuttgar, 336 p.

García-Gurría, L., Salinas-Hernandez, R., Ulín-Montejo, F., Petit-Jimenez, D., Baez-Sañudo, R., MercadoRuíz, J., (2013). Effect of packaging on the conservation of rambutan (Nephelium lappaceum L.) stored in refrigeration. Iberoam J Post-harvest Tec. 14 (2).101-108.

Gerardo, M. C. (2014). Comportamiento Reproductivo y Calidad del Fruto de Mango Ataulfo (Mangifera caesia Jack ex Wall.) Como Respuesta a un Manejo Agroecológico en Tapachula. Chiapas. Tesis como requisito para obtener el grado de: Maestro en Ciencias en Producción Agropecuaria Tropical. México. 52 p.

Godoy, T. G. C., Reyes, N. 2007. Estudio de sector: Rambután. Programa Interinstitucional integrado para diversificación de las exportaciones en Honduras (PIIDEH). Tegucigalpa. 87p. Disponible en http:// www.sic.gob.hn/promocion/new\%20folder/estudio\%20de\%20sector\%20 rambutan.pdf.

Gómez, G. R., González L. M. I., Agüero, A. R., Mexzón V. R., Herrera, M. F., Rodríguez, R. A. M. (2017). Conocimiento sobre coberturas vivas y disposición a utilizarlas por productores de varios cultivos. Agronomía Mesoamericana. 28(2): 45-65. Doi: 10.15517/ma.v28i2.23403

Hernández, C., Ascacio-Valdes, J., De la Garza, H., Wong-Paz, J., Aguilar, G.N., Martínez-Avila, G.C., Castro-López, C., Aguilera-Carbo, A. (2017). Polyphenolic content, in vitro antioxidant activity and chemical composition of extract from Nephelium lappaceum L. (Mexican rambutan) husk. Asian Pacific Journal of Tropical Medicine, 10(12): 1201-1205. Doi: 10.1016/j.apjtm.2017.10.030

Instituto Nacional de Estadística y Geografía (INEGI). (2020). Anuario estadístico y geográfico por entidad federativa. México. 2020. 858p. [En línea] Accesado: 12 de junio 2021. Disponible en: https:// www.inegi.org.mx/contenidos/productos/prod_serv/contenidos/espanol/bvinegi/productos/nueva_ estruc/702825197506.pdf

IUSS Working Group WRB. (2015). World Reference Base for Soil Resources 2014. update 2015. International soil classification system for naming soils y creating legends for soil maps. World Soil Resources Reports No. 106. FAO. Rome.

Leyva, A. (2002). El Arrope: Una técnica Agroecológica para conservar la humedad del suelo bajo el cultivo del plátano. Agricultura Orgánica. 8 (1): 26-28.

Ling, L., Radhakrishnan, A., Subramaniam, T., Cheng, H.,Palanisamy, U. (2010). Assessment of antioxidant capacity and cytotoxicity of selected Malaysian plants. Molecules. 15 (4). 2139-2151. Doi: 10.3390/ molecules 15042139

López, G. A. (2016). Aumenta Producción de Rambután en la Región. Disponible en: www.diariodechiapas. com.mx

Manaharan T, Palanisamy U., Ming C. (2012). Tropical plant extracts as potential antihyperglycemic agents. Molecules. 17(5): 5915-5923. Doi: 10.3390/molecules17055915

Marroquín, A. F. J., Gehrke, V. M. R., Pohlan, J. A., Lerma, M. J. N., Toledo, T. E., Ley, C. A. (2015). The Association of Bushy Legumes with 'Ataúlfo' Mango (Mangifera indica L.) cv. Ataúlfo Affects Reproductive Biology y Enhances Productivity in Mango Plantations in Soconusco. Chiapas. México. Indian Horticulture Journal. 5 (3/4): 63-69.

Méndez, E. J. A., Ramírez. J. J.( 2007). Transformaciones Territoriales Y Estrategias De Supervivencia En La Región Soconusco Del Estado De Chiapas. México. Seminario ¿Exclusión o recomposición 
del campesinado en América Latina? No. Del Simposio: RU1. V Congreso Europeo Ceisal de Latinoamericanistas. Bruselas.

Mohamed, S., Hassan, Z., Hamid, N. (1994). Antibacterial activity of sometropical fruits wastes (guava, starfruit, banana, papaya, passionfruit, langsat, duku, rambutan and rambai). Pertanika J Trop Agric Sci. 17: 219-227.

Nakasone. H.; Paull. (1998). R. Tropical fruits. CAB International. NY.

Palanisamy, U., Ling, L., Manaharan, T., Appleton, D. (2011). Rapid isolation of geraniin from Nephelium lappaceum rind and its antihyperglycemic activity. Food Chem. 127(1): 21-27. Doi: 10.1016/j. foodchem.2010.12.070

Pérez, R. A., Pohlan, J. (2004). Prácticas de cosecha y poscosecha del rambután en el Soconusco. Chiapas. México. LEISA Rev. Agroecol. 20(3): 24-26.

Robles, H. (2012). El papel central de los pequeños productores en una nueva estrategia de desarrollo rural en José Luis Calva (coordinador). Políticas agropecuarias. forestales y pesqueras. Análisis estratégico para el desarrollo. Vol. 9. Consejo Nacional de Universitarios/Juan Pablos Editor. México. pp. 95-115.

Ruiz, G. J. A., Medina G. G., González, A. I.J., Flores, L. H.E., Ramírez, O. G., Ortiz, T. C., Byerly, M. K. F., Martínez, P. R. A. (2013). Requerimientos agroecológicos de cultivos. Segunda Edición. Libro Técnico Núm. 3. INIFAP. Instituto Nacional de Investigaciones Forestales Agrícolas y Pecuarias-CIRPACCampo Experimental Centro Altos de Jalisco. Tepatitlán de Morelos. Jalisco. México. 564 p.

Secretaría de Agricultura. Ganadería. Desarrollo Rural. Pesca y Alimentación (SAGARPA). (2015). Agenda Técnica Agrícola de Chiapas. Segunda edición. México. 249 p.

Servicio de Información Agroalimentaria y Pesquera (SIAP). (2020). Disponible en: https://www.gob.mx/siap/ acciones-y-programas/produccion-agricola-33119

Thitilertdecha, N., Teerawutgulrag, A., Kilburn, J., Rakariyatham, N. (2010). Identification of major phenolic compounds from Nephelium lappaceum L. and their antioxidant activities. Molecules. 15 (3): 1453-1465. Doi: $10.3390 /$ molecules 15031453

Tindall, H. D. (1994). Food and Agriculture Organization of the United Nations. (1994). Rambutan cultivation. Rome: Food and Agriculture Organization of the United Nations. U. G. Menini, A. J. Hodder (Eds). Food \& Agriculture Org. 163 p.

Toledo, E. T. (2008). La cosecha en verde y conservación in situ de los residuos de la caña de azúcar (Saccharum spp.) impacto en la sostenibilidad y restauración del agroecosistema en Huixtla. México. Tesis Doctor en Ciencias Estadísticas. Instituto Nacional de Ciencias Agrícola. Habana. Cuba. 100 p.

Vanderlinden, E. J. M., Pohlan, H. A. J., Janssens, M.J.( 2004). Culture y fruit quality of rambutan (Nephelium lappaceum L.) in the Soconusco region. Chiapas. México. Fruits. 59 (5): 339-350.

Vargas, A. (2003). Descripción morfológica y nutricional del fruto de rambután (Nephellium lappaceum L.). Agronomía Mesoamericana.14(2): 201-206. 